\title{
PROTECTING TRADE SECRETS THROUGH COPYRIGHT
}

For inany years businesses have taken steps to protect valuable trade secrets. ${ }^{1}$ Often these steps have severely restricted access to special documents or to areas of inanufacturing plants that contain secret inachinery. ${ }^{2}$ Businesses commonly require employees to sign pledges not to disclose trade secrets during or after their employment. ${ }^{3}$ Additionally, hicensing agreements frequently contain clauses that prohibit the dissemination of secrets or their use following the termination of the agreements. ${ }^{4}$ Courts sometimes will imply these clauses, ${ }^{5}$ even if they are not included expressly in the licensing agreeinents. Recently, soine businesses have attempted to gain additional protection by affixing copyright notices to their secrets. ${ }^{6}$ The wisdom of this practice has yet to be examined closely.

In 1980 the American Bar Association Committee on Trade Secrets and Interference with Contracts considered for the first time the propriety of marking trade secrets or confidential inaterials with a copyright notice. ${ }^{7}$ The committee concluded that no inconsistency arises in placing a copyright notice on material that bears an admointion forbidding disclosure to third parties. The committee viewed copyright protection as a "backup or compleinent" to laws prohibiting theft or misappropriation of trade secrets. ${ }^{8}$ A minority of the commit-

1. See R. Ellis, Trade Secrets $\$ \S 1-16$ (1953).

2. See Pakula, Non-Contractual In-House Procedures for Confidential Information, in PROTECTING TRADE SECRETS TODAY 179-87 (T. Annold ed. 1973) [hereinafter cited as TRADE SECRETS]. See generally Adams, Protecting a Company's Trade Secrets from Theft by Its Employees, in Protecting and Profiting from Trade Secrets 1979, at 303-43 (R. Milgrim ed. 1979).

3. See Arnold \& Jackson, The Peripatetic Employee and the Protection of Trade Secrets, in Trade SECRETs, supra note 2, at 149-77. See also Water Servs., Inc. v. Tesco Chems., Inc., 410 F.2d 163 (5th Cir. 1969); Motorola, Inc. v. Fairchild Camera \& Instrument Corp., 366 F. Supp. 1173 (D. Ariz. 1973); Irvington Varmish \& Insulator Co. v. Van Norde, 138 N.J. Eq. 99, 46 A.2d 201 (1946); Kadis v. Britt, 224 N.C. 154, 29 S.E.2d 543 (1944).

4. See Painton \& Co. v. Bournes, Inc., 442 F.2d 216 (2d Cir. 1971). See generally Bassler \& Bayes, Process Licensing, in TRADE SECRETS, supra note 2, at 233.

5. See, e.g., Servo Corp. of America v. General Elec. Co., 337 F.2d 716 (4th Cir. 1964) (holding the improper exploitation of a confidential relationship actionable on the theory of unjust enrichment), cert. denied, 383 U.S. 934 (1966).

6. See Wall St. J., Dec. 29, 1980, at 26, col. 5.

7. A.B.A. Section of Patent, TRademark and Copyright LaW, Committee Reports $218(1980)$.

8. Id. 
tee was concerned, however, that affixing a copyright notice suggests a publication of material, which is inconsistent with a secrecy warning. ${ }^{9}$

This note examines the practice of placing a copyright notice on trade secrets. It defines the term "trade secrets," shows how the law protects these secrets, and examines the purposes of trade secret law. The note then analyzes the scope of the Copyright Act of $1976,{ }^{10}$ discusses how a copyright owner enforces his rights, and reviews the purposes behind copyright law. With this conceptual framework in place, the validity of placing a copyright notice on trade secrets is discussed. The note addresses two problems-first, whether placing a copyright notice on trade secrets invokes the preemption doctrime of section 301 of the Act, ${ }^{11}$ and second, whether the deposit requirement of the Act ${ }^{12}$ can be interpreted to accominodate trade secrets.

\section{Trade Secrets Law}

\section{A. Definition of a "Trade Secret."}

In general, state law protects trade secrets. ${ }^{13}$ The inost cominonly cited definition of a trade secret is found in the Restatement of Torts:

A trade secret may consist of any formula, pattern, device or compilation of information which is used im one's busimess and which gives him an opportunity to obtain an advantage over competitors who do not know or use it. It may be a formula for a chemical compound, a process of manufacturing, treating, or preserving materials, a pattern for a machine or other device, or a list of customers. ${ }^{14}$

In Schulenburg $v$. Signatrol, Inc. ${ }^{15}$ the court defined a trade secret as a "secret plan or process, tool, mechanism or compound known only to its owner and those of his employees to whoin it is necessary to confide it."16 These general definitions suggest two requirements for a vahid trade secret. First, a trade secret should display some degree of nov-

9. Id. 218-19.

10. 17 U.S.C. $\$ 8101-810$ (1976 \& Supp. III 1979).

11. 17 U.S.C. \& 301 (1976).

12. Id. $\S 407$.

13. See R. ElLIS, supra note 1, \$§ 1-16.

14. Restatement of Torts \& 757, Comment b (1939). The Restatement (Second) of ToRTs omitted this section because the fields of unfair competition and trade regulation "were rapidly developing into independent bodies of law with diminishing reliance upon the traditional principles of Tort law." 4 Restatement (SECOND) OF ToRTs, Introductory Note to Division Nine, at 1 (1979). Nevertheless, this definition of trade secrets is still valid. See Kewanee Oil Co. v. Bicron Corp., 416 U.S. 470, $474-75$ (1974); Umion Carbide Agricultural Prods. Co. v. Costle, 632 F.2d 1014, 1016-17 (2d Cir. 1980), cert. denied, 450 U.S. 996 (1981); Fisher Stoves, Inc. v. All Nighter Stove Works, Inc., 626 F.2d 193, 196 (Ist Cir. 1980); Basso Chems., Inc. v. Schmidt, 522 F. Supp. 1087, 1091-92 (E.D. Ark. 1981).

15. 33 Ill. $2 \mathrm{~d}$ 379, 212 N.E.2d 865 (1965), cert. denied, 383 U.S. 959 (1966).

16. 33 Ill. $2 \mathrm{~d}$ at 385,212 N.E. $2 \mathrm{~d}$ at 868 . 
elty. ${ }^{17}$ This requirement does not mean, however, that the product must reach the level of invention or patentability. ${ }^{18}$ In fact, trade secrets include not only inventions and processes, but also "knowhow." 19 The information or knowledge must merely represent to some appreciable degree the independent efforts of its claimant. ${ }^{20}$ For instance, the courts have declined to protect the "general approach" of a process but have allowed protection of the "specifications and relationships" used in the process. ${ }^{21}$ Conversely, a valid trade secret can exist im a combimation of components each part of which is in the public domam, but which constitute a unique achieveinent when combined. ${ }^{22}$

The second requirement for a trade secret is that it be truly secret-it "must not be a part of the public knowledge or of general knowledge in the trade or busmess involved." 23 To be certain of obtaining protection under trade secret law, the proprietor of information should take reasonably prudent steps to maintain the secrecy of his idea by disclosing it im confidence only to key employees and technical consultants. ${ }^{24}$ Absolute secrecy is not essential, however, and one does not abandon his idea to the public by revealing it to non-employees in

17. Kewanee Oil Co. v. Bicron Corp., 416 U.S. 470, $475-78$ (1974); see Smith v. Dravo Corp., 203 F.2d 369, 373 (7th Cir. 1953); Plastic \& Metal Fabricators, Inc. v. Roy, 163 Conn. 257, 265, 303 A.2d 725, 729 (1972).

18. Kewanee Oil Co. v. Bicron Corp., 416 U.S. 470, 476 (1974); W.R. Grace \& Co. v. Hargadine, 392 F.2d 9, 14 (6th Cir. 1968); see Becker v. Contoure Laboratories, Inc., 279 U.S. 388, 391 (1929); Snith v. Dravo Corp., 203 F.2d 369, 373 (7th Cir. 1953); Ungar Elec. Tools, Inc. v. Sid Ungar Co., 192 Cal. App. 2d 398, 403, 13 Cal. Rptr. 268, 271 (1961).

19. See Hooker Chem. Corp. v. Velsicol Chem. Corp., 235 F. Supp. 412 (W.D. Tenn. 1964) (upholding a licensing agreenent in which one party paid a royalty for the use of another's "know-how").

20. Snith v. Dravo Corp., 203 F.2d 369, 373 (7th Cir. 1953); see A.O. Snnth Corp. v. Petroleum Iron Works Co., 73 F.2d 531, 538 (6th Cir. 1934), modified to increase scope of injunction, 74 F.2d 934 (6th Cir. 1935).

21. Winston Research Corp. v. Minnesota Mining \& Mfg. Co., 350 F.2d 134, 139 (9th Cir. 1965) (the court did not protect the general approach of a process to reduce the inertia of rotating parts and to use a wide-band servo system in precision tape recorders but did shield froin disclosure the specifications of components and their interrelatiouships).

22. Imperial Chen. Indus. Ltd. v. National Distillers \& Chem. Corp., 342 F.2d 737, 742 (2d Cir. 1965). In this case the court determined that eight of nine components in a machine were known as separate components. The court afforded protection to a process using these parts because they were arranged, along with one urique part, in an original manner. $C f$. Sarkes Tarzian, Inc. v. Audio Devices, Inc., 166 F. Supp. 250 (S.D. Cal. 1958) (manufacturing process held not to be a trade secret when only one basic method is feasible and the steps within the process are variable only to an insignificant degree).

23. McAlpine v. Aamco Automatic Transmissious, Inc., 461 F. Supp. 1232, 1256 (E.D. Mich. 1978). Actually, novelty and secrecy are closely related, because if something is not novcl, generally it is not secret. Id.

24. See Plastic \& Metal Fabricators, Inc. v. Roy, 163 Conn. 257, 303 A.2d 725 (1972). 
confidence or through limited publication. ${ }^{25}$ For example, disclosure to a licensee or potential licensee does not result in forfeiture of the secret. 26

\section{B. Protection of Trade Secrets.}

Trade secret law protects the trade secret owner in two ways. First, it enforces confidential relationships, and second, it prevents disclosure of trade secrets by those who have obtamed them by improper means.

Trade secrets are protected by the establishment of relationships between the discloser and his disclosees. ${ }^{27}$ Without such relationships there would be no protection. As Justice Holmcs observed in E.I. Du Pont de Nemours Powder Co. v. Masland:28

The word property as applied to ... trade secrets is an unanalyzed expression of certain secondary consequences of the primary fact that the law makes solne rudimentary requirements of good faith .... . The property may be demed but the confidence cannot be. Therefore the starting point for the present matter is not property or due process of law, but that the defendant stood in confidential relations with the plaintiffs . . . .29

Hence, the law protects agaimst the disclosure or unauthorized use of a trade secret by those to whom the secret has been confided under goodfaith restrictions of confidentiality and nonuse. ${ }^{30}$ This protection applies to personnel both outside ${ }^{31}$ and inside ${ }^{32}$ the secret-holder's business organization. These restrictions have been grounded in four

25. McAlpine v. Aamco Automatic Transmissions, Inc., 461 F. Supp. 1232, 1256 (E.D. Mich. 1978); Plastic \& Metal Fabricators, Inc. v. Roy, 163 Conn. 257, 268, 303 A.2d 725, 731 (1972); see Board of Trade v. Christie Grain \& Stock Co., 198 U.S. 236, 250-51 (1905).

26. See Lear, Inc. v. Adkins, 395 U.S. 653, 671-72 (1969); McAlpine v. Aamco Automatic Transmissions, Inc., 461 F. Supp. 1232, 1256 (E.D. Mich. 1978).

27. See Annold, Shadows Do Not Fight, in Trade SECRETS, supra note 2, at 67.

28. 244 U.S. 100 (1917).

29. Id. at 102.

30. See Servo Corp. of America v. Geueral Elec. Co., 337 F.2d 716, 724-25 (4th Cir. 1964); Franke v. Wiltschek, 209 F.2d 493, 495 (2d Cir. 1953); Schreyer v. Casco Prods. Corp., 190 F.2d 921, 924 (2d Cir. 1951).

31. See cases cited in uote 30 supra.

32. See B.F. Goodrich Co. v. Wohlgemuth, 117 Ohio App. 493, 192 N.E.2d 99 (1963). In Goodrich the einployer had disclosed to an employee confidential know-how relating to spacesuits. A competitor subsequeutly had hired the einployee. Eveu though the einployee had not disclosed the informatiou acquired from his former einployer, the court held that a substantial threat of disclosure existed and granted an imjunction which prohibited the employce from working on spacesuits. See also E.I. Du Pont de Neinours \& Co. v. American Potash \& Chem. Corp., 41 Del. Ch. 533, 200 A.2d 428 (1964). 
theories of law: ${ }^{33}$ breach of confidence, ${ }^{34}$ protection of discoveries, ${ }^{35}$ unfair competition, ${ }^{36}$ and implied contract. ${ }^{37}$

The law also protects the owner of a trade secret when the knowledge is gained by "improper means" and not through the volitional act of the owner. ${ }^{38}$ Improper means include tlieft, wiretapping, fraudulent misrepresentations to induce disclosure, and other kinds of espionage. ${ }^{39}$

Trade secret law, however, does not protect against discovery by fair and honest means. ${ }^{40}$ Accidental disclosure, independent invention, and discovery through reverse-engineering are examples of fair and honest methods of acquiring another's trade secret. ${ }^{41}$ Any person is free to develop, use, and publish works containing the same concept as that of the trade secret holder so long as he acquires the secret by honest means. ${ }^{42}$

\section{Purpose of Trade Secret Law.}

Trade secret laws have multiple purposes. First, they encourage the development of new ideas by protecting their developers, thus al-

33. See Marcuse, The Protection of Trade Secrets: Theory and Practice, 36 ConN. B.J. 348, 351-53 (1962). The author lists five theories underlying trade secret protection, including a property right theory. He notes, however, that this property right is limited by the independent ability of others to discover the same processes through their own ingenuity. Such a right, then, is not really a property right at all because the secret is protected only through the assertion of one of the other four rights.

34. See Kewanee Oil Co. v. Bicron Corp., 416 U.S. 470, 475 (1974); E.I. Du Pont de Nemours Powder Co. v. Masland, 244 U.S. 100, 101 (1917); Servo Corp. of America v. General Elec. Co., 337 F.2d 716, 724-25 (4th Cir. 1964); Franke v. Wiltschek, 209 F.2d 493, 495 (2d Cir. 1953).

35. See Peabody v. Norfolk, 98 Mass. 452, 461 (1868); Tabor v. Hoffman, 118 N.Y. 30, 34, 23 N.E. 12,12 (1889).

36. See Schreyer v. Casco Prods. Corp., 190 F.2d 921, 924 (2d Cir. 1951).

37. See Warner-Lambert PharmaecuticaI Co. v. John J. Reynolds, Inc., 280 F.2d 197 (2d Cir. 1960) (per curiam).

38. E.I. Du Pont de Nemours \& Co. v. Christopher, 431 F.2d 1012, 1015 (5th Cir. 1970), cert. denied, 400 U.S. 1024 (1971) (The improper act involved the use of aerial plotography); see Imperial Chem. Indus. Ltd. v. National Distillers \& Chem. Corp., 342 F.2d 737, 743 (2d Cir. 1965); Smith v. Dravo Corp., 203 F.2d 369, 374-75 (7th Cir. 1953).

39. Restatement OF TORTS $\$ 757$, Comment $\mathrm{f}$ (1939). This comment provides:

The discovery of another's trade secret by improper means subjects the actor to liability imdependently of the harm to the interest in the secret . . . . But ineans may be improper under this rule even though they do not cause any other harm than that to the interest in the trade secret. Examples of such means are fraudulent misrepresentations to induce disclosure, tapping of telephone wires, eavesdropping or other espionage. A complete catalogue of improper means is not possible. In general, they are means which fall below the generally accepted standards of commercial inorality and reasonable conduct.

40. Kewanee Oil Co. v. Bicron Corp., 416 U.S. 470, 476 (1974); National Tube Co. v. Eastern Tube Co., 13 Ohio C.C. Dec. 468, 471 (1902), affd, 69 Ohio St. 560, 70 N.E. 1127 (1903).

41. Kewanee Oil Co. v. Bicron Corp., 416 U.S. 470, 476 (1974).

42. See Arnold, supra note 27, at 68 . 
lowing them to enjoy the rewards of their work. ${ }^{43}$ Second, they uphold private agreeinents for the licensing of trade secrets on mutually acceptable terms and thereby encourage the owner to share his new developments with those who are willing to pay him royalties. ${ }^{44}$ The system also provides further incentive for the dissemination of new ideas by allowing others to develop the same ideas independently and perhaps to improve on these ideas. ${ }^{45}$ Furthermore, by affording protection to secrets that do not reach the level of patentability, ${ }^{46}$ the trade secret laws encourage developinent in those areas into which patent law does not extend. ${ }^{47}$

\section{Copyright LAW}

Defining the himits of copyright law is a difficult task because there is no agreement on the law's conceptual basis. ${ }^{48}$ Nevertheless, one can discern the general boundaries of copyright law by examining the subject inatter of copyright and by determining the rights granted under the Copyright Act of 1976.49

\section{A. Scope of Copyright.}

The Act extends copyright protection to original works of authorship fixed in any tangible inedium of expression from which the works can be perceived, reproduced, and otherwise comınunicated. ${ }^{50}$ Works of autliorship specifically imclude: (1) literary works; (2) musical works, imcluding any accoinpanying words; (3) dramatic works, imcluding any accompanying music; (4) pantomimes and choreographic

43. McAlpine v. Aamco Automatic Transmissions, Inc., 461 F. Supp. 1232, 1256 (E.D. Mich. 1978); see Umited States v. Dubilier Condenser Corp., 289 U.S. 178, 186 (1933); Tabor v. Hoffman, 118 N.Y. 30, 37, 23 N.E. 12, 13 (1889); Arnold, supra note 27, at 70-71. See generally Kewance Oil Co. v. Bicron Corp., 416 U.S. 470, 484-87 (1974); Painton \& Co. v. Bourns, Inc., 442 F.2d 216, 22325 (2d Cir. 1971).

44. Painton \& Co. v. Bourns, Inc., 442 F.2d 216, 223 (2d Cir. 1971); see 84 HaRv. L. Rev. 477, 484 (1970).

45. The longer one keeps his trade secret to himself the greater are the chances that someone else will discover the idea. Once someone else discovers the know-how, there is a chance that the market for the licensing of the technology will diminish. See Amold, supra note 27, at 69, noting that, in all but a few cases, trade secret protection is short-lived.

46. In Painton \& Co. v. Bourns, Inc., 442 F.2d 216, 224 (2d Cir. 1971), the court divided trade secrets into three categories: (1) those that are believed to be patentable; (2) those known not to be patentable; and (3) those of dubious patentability. All three of these categories can be protected under trade secret law. See notes 18-22 supra and accompanying text.

47. See Painton \& Co. v. Bourns, Inc., 442 F.2d 216 (2d Cir. 1971).

48. See Patterson, An Analysis of the 1976 Copyright Act, 3 AM. L. Inst.-A.B.A. Course MATERIALS J. 21, 22 (1978).

49. 17 U.S.C. $\$ \S 101-810$ (1976 \& Supp. III 1979).

50. Id. \& 102(a) (1976). 
works; (5) pictorial, graphic, and sculptural works; (6) motion pictures and other audiovisual works; and (7) sound recordings. ${ }^{51}$ Copyright protection also covers compilations and derivative works. ${ }^{52}$

Copyright protection encompasses only the expression of an idea, however, and not the idea itself. ${ }^{53}$ This notion is now codified in the Act and has long been advanced in court decisions, starting with Baker v. Selden. ${ }^{54}$ In that case the Supreme Court refused an author's claim to an exclusive property right in a systenn of bookkeeping that he had exhibited and explained in a copyrighted treatise..$^{55}$ The Court noted that the "very object of publishing a book on science or the useful arts is to communicate to the world the useful knowledge which it contains."56 This purpose "would be frustrated if the knowledge could not be used without imcurring the guilt of piracy of the book."57 Therefore, the Court held that the description of the system contained in the treatise was protected, but the idea, the system itself, was not. ${ }^{58}$

Although either novelty or uniqueness is required for trade secrets, neither characteristic is required for a copyrighted work..$^{59}$ Copyright is available for any work that represents the author's original thought. ${ }^{60}$

\section{Id.} $\S 101$.

52. Id. § 103. For definitions of the terms "compilation" and "derivative work," see $i d$.

53. Id. \& 102(b). This subsection provides: "In no case does copyright protection for an original work of authorship extend to any idea, procedure, process, system, method of operation, concept, principle, or discovery, regardless of the forn in which it is described, explained, illustrated, or embodied in such work." See also U.S. Copyright OfFiCE, LIBRARY of CoNGress, CIR. No. 31, IdeAs, Plans, Methods OR Systems (1978).

54. 101 U.S. 99 (1879); see, e.g., Mazer v. Stein, 347 U.S. 201, 217 (1954); Franklin Mint Corp. v. National Wildlife Art Exch., Inc., 575 F.2d 62, 64 (3d Cir.), cert. denied, 439 U.S. 880 (1978); Reyher v. Children's Television Workshop, 533 F.2d 87, 90 (2d Cir.), cert. denied, 429 U.S. 980 (1976); Universal Athletic Sales Co. v. Salkeld, 511 F.2d 904, 906 (3d Cir. 1975); Gibson v. CBS, Inc., 491 F. Supp. 583, 584-85 (S.D.N.Y. 1980).

55. 101 U.S. at 104-07.

56. Id. at 103.

57. Id.

58. Id. at 102-07.

59. Franklin Mint Corp. v. National Wildlife Art Exch., Inc., 575 F.2d 62, 64 (3d Cir.), cert. denied, 439 U.S. 880 (1978); National Comics Publications, Inc. v. Fawcett Publications, Inc., 191 F.2d 594, 599-600 (2d Cir. 1951), opinion clarifed per curiam, 198 F.2d 972 (2d Cir. 1952); Sheldon v. Metro-Goldwyn Pictures Corp., 81 F.2d 49, 53-54 (2d Cir.), cert. denied, 298 U.S. 669 (1936); Russell v. Trimfit, Inc., 428 F. Supp. 91, 93 (E.D. Pa. 1977), aff'd, 568 F.2d 770 (3d Cir. 1978); Leeds Music Ltd. v. Robin, 358 F. Supp. 650, 659 (S.D. Ohio 1973). See also Chafee, Reflections on the Law of Copyright: I, 45 COLum. L. REv. 503, 505 (1945).

60. Roth Greeting Cards v. United Card Co., 429 F.2d 1106, 1109 (9th Cir. 1970); Lin-Brook Builders Hardware v. Gertler, 352 F.2d 298, 301 (9th Cir. 1965); Russell v. Trimfit, Inc., 428 F. Supp. 91, 93 (E.D. Pa. 1977), aff'd, 568 F.2d 770 (3d Cir. 1978); 1 M. Nimmer, CoPYright $\& 2.01$ (1981). 
The work need only be created without actual copying. ${ }^{61}$ In fact, so long as there is no plagiarism, there is no requirement that the work differ substantially from prior works or that it contribute anything of value to society. ${ }^{62}$

\section{B. Nature and Enforcement of the Copyright Owner's Rights.}

Assuming that a given work is within the subject matter of copyright protection, the creator of the work possesses certain exclusive rights in that work. He has the sole rights to (1) reproduce the work in copies or phonorecords; (2) prepare derivative works based on the copyrighted original; (3) distribute copies to the public by sale, lease, and so forth; (4) perform the work publicly; and (5) display the work publicly. ${ }^{63}$ The Act, lowever, places some limitations on these exclusive rights. ${ }^{64}$ The nost important of these limitations is the codified doctrime of fair use, ${ }^{65}$ which allows one to copy a copyrighted work, without fear of infringing the copyright, if the copying is done for the purpose of criticism, comment, news reporting, teaching, scholarship, or research. ${ }^{66}$ Other restrictions on the exclusive rights of the creator are much narrower and apply only in specific situations, such as secondary transmissions by cable television systems ${ }^{67}$ and transfers of particular copies of plionorecords. ${ }^{68}$

The rights of the copyright owner vest initially in the autlior of the work $^{69}$ at the moment the work is created. ${ }^{70}$ These rights are separable

61. Wihtol v. Wells, 231 F.2d 550, 553 (7th Cir. 1956); Alfred Bell \& Co. v. Catalda Fine Arts, Inc., 191 F.2d 99, 102 (2d Cir. 1951); Russell v. Trimfit, Inc., 428 F. Supp. 91,93 (E.D. Pa. 1977), aff'd, 568 F.2d 770 (3d Cir. 1978). 1978).

62. Russell v. Trimfit, Inc., 428 F. Supp. 91,93 (E.D. Pa. 1977), aff'd, 568 F.2d 770 (3rd Cir.

63. 17 U.S.C. $\S 106(1)-(5)$ (1976).

64. See id. $\$ \S 107-118$.

65. Id. $\S 107$. This section provides:

In determining whether the use made of a work in any particular case is a fair use the factors to be considered shall include-

(1) the purpose and character of the use, mcluding whether such use is of a commercial nature or is for nonprofit educatioual purposes;

(2) the nature of the copyrighted work;

(3) the amount and substantiality of the portion used in relation to the copyrighted work as a whole; and

(4) the effect of the use upon the potential unarket for or value of the copyrighted work.

66. Id. The limitations of fair use are still being thrashed out in the courts. For a good summary of recent cases in this area, see Johnston, Exclusive Rights of Copyright; Fair Use; Reproduction by Libraries; Effect of Transfer of Particular Copy or Phonorecord, im CURRENT DEvelopMENTS IN Copyright LAw 1980, at 93, 116-21 (R. Danny ed. (1980)).

67. 17 U.S.C. $\$ 111$ (1976).

68. Id. $\S 109$.

69. Id. \$ 201(a)-(c) (Supp. III 1979).

70. Id. § 302(a) (1976). 
and transferable ${ }^{71}$ and generally last for a term equal to the hife of the author plus fifty years. ${ }^{72}$

An owner of rights under a vahd copyright can enforce his rights against violators by bringing an action for infrimgennent. ${ }^{73}$ If a court holds the owner's claim of infringement to be vahid, the court can then issue a teinporary or permanent injunction to prevent or restrain the infringeinent. ${ }^{74}$ The court also can order the destruction or other reasonable disposition of any existing infringing itens. ${ }^{75}$ The infringer can be liable to the copyright owner for actual damages plus the infringer's profits ${ }^{76}$ or for statutory dainages. ${ }^{77}$ Criminal penalties are also available. ${ }^{78}$

\section{Purpose of Copyright.}

In essence, copyright gives its holder a monopoly interest in the copyrighted work. ${ }^{79}$ The Act grants exclusive rights ${ }^{80}$ that are, subject to a few exceptions, ${ }^{81}$ enforceable against anyone. ${ }^{82}$ This monopoly extends only to the expression of the idea, however, and not to the idea itself. ${ }^{83}$

The different treatment accorded ideas and expressions can be explained, in part, by the so-called patent and copyright clause of the United States Constitution. ${ }^{84}$ This clause provides that " $[t]$ he Congress

71. Id. \&210(d) (Supp. III 1979).

72. Id. $\$ 302$ (a) (1976).

73. Id. $\$ 501$. No one can maintain an mfringement action until he has properly registered a copyright claim with the Copyright Office, $i d . \S 411$, and has met the requirements for notice and deposit contained in the Act. Id. $\$ \$ 401-408$. Moreover, if one is a transferee of a right under a valid copyright, he must record the document of transfer with the Copyright Office before he can properly bring an action for infringement. Id. § 205(d).

74. Id. $\$ 502(\mathrm{a})$.

75. Id. $\$ 503(\mathrm{~b})$.

76. $I d . \$ 504(\mathrm{~b})$.

77. Id. $\$ 504(\mathrm{c})$. The court also can award court costs and attorney's fees to the successful party. Id. $\S 505$.

78. Id. $\S 506$. This section provides a maximum fine of $\$ 10,000$ and imprisonment for up to one year. For infringennent of sound recording or motion picture copyrights, violators are subject to maximum penalties of $\$ 25,000$ and one year in prison for the first offense, and $\$ 50,000$ and two years in prison for subsequent offenses. Id.

79. See Washingtonian Publishing Co. v. Pearson, 306 U.S. 30, 39 (1939); Herbert v. Shanley Co., 242 U.S. 591, 594 (1917); Chess Music, Inc. v. Sipe, 442 F. Supp. 1184, 1185 (D. Minn. 1977).

80. See text accoinpanying note 63 supra.

81. See notes 64-68 supra and accompanying text.

82. Section 501 of the Act provides that "[a]nyone who violates any of the exclusive rights of the copyright owner as provided by sections 106 through 118 . . . is an infringer of the copyright." 17 U.S.C. \& 501 (1976) (emphasis added).

83. See notes 53-58 supra and accompanying text.

84. U.S. CoNST. art. I, § 8, cl. 8. 
shall have Power . . . [t]o promote the Progress of Science and useful Arts, by securing for limited Times to Authors and Inventors the exclusive Right to their respective Writings and Discoveries . . ."85 The clause was designed to encourage individual creative effort by affording the opportunity for personal gain to authors and inventors, thus advancing the public welfare by rewarding creativity. ${ }^{86}$ Copyright law has a similar purpose-to attract private investment to the production of origimal expression. ${ }^{87}$ The hope of acquiring property rights in the created expressions is the inducement. ${ }^{88}$ Permitting copyright to apply to ideas, however, would withdraw those concepts from the supply of inaterials open to other authors and thus narrow the field of thought available for development. ${ }^{89}$

\section{Use of Copyright to Protect Trade Secrets}

The preceding two sections have described separate and distinct legal systems designed to encourage developinent of new ideas, processes, and technologies. Yct it is not clear that one system can be used to suppleinent the other. There are serious problems with the use of copyright law to protect trade secrets.

\section{A. The Scope of Protection.}

Trade secrets are, in essence, ideas. ${ }^{90}$ Trade secret law is designed to protect these ideas.91 Copyright law does not protect ideas, however, but only the expression of ideas..$^{92}$ For exainple, assume one develops a novel process for rustproofing cars and places a copyright notice on the sheet containing a description of the process. So long as this rustproofing system is kept secret, trade secret laws provide sanctions against disclosure by einployees or licensees. But suppose a breeze blows the

\section{Id.}

86. See Twentieth Century Music Corp. v. Aiken, 422 U.S. 151, 156 (1975); Mazer v. Stein, 347 U.S. 201, 219 (1954); Pearson v. Washingtonian Publishing Co., 306 U.S. 30, 36 (1938); Bell v. Pro Arts, Inc., 366 F. Supp. 474, 482 (N.D. Ohio 1973), aff'd, 511 F.2d 451 (6th Cir.), cert. denied, 423 U.S. 829 (1975); Lemer v. Schectman, 228 F. Supp. 354, 358 (D. Minn. 1964).

87. See Goldstein, Preempted State Doctrines, Involuntary Transfers and Compulsory Licenses: Testing the Limits of Copyright, in Protecting and Profiting from Trade SeCrets 1979, at 436, 436 (R. Milgrim ed. 1979).

88. Id.

89. Becker v. Loew's, Inc., 133 F.2d 889, 891 (7th Cir.), cert. denied, 319 U.S. 772 (1943); see Nichols v. Universal Pictures Corp., 45 F.2d 119 (2d Cir. 1930), cert. denied, 282 U.S. 902 (1931) (a playwright cannot prohibit others froln using his idea). See also $3 \mathrm{M}$. NIMMER, CopYriGHT \& 16.01 (1981).

90. See notes 14-22 supra and accompanying text.

91. See notes $27-42$ supra and accompanying text.

92. See notes 53-58 supra and accoinpanying text. 
descriptive sheet off the inventor's desk and through a window, and a passerby finds it. Trade secret law no longer offers any protection because there is neither a confidential relationship to be enforced nor improper conduct to be punished. ${ }^{93}$ Copyright law might prohibit the stranger from copying the description and publishing it, but lie could still use the process without infringing the copyright.

The decision in Russell $v$. Trimfit ${ }^{94}$ supports this theory. In Russell the plaintiff copyrighted drawings of mitten toe or glove socks. The defendant manufactured similar socks, and the plaintiff sued for infringement. The court dismissed the action, noting the absence of any allegation that the defendant had ever produced, inanufactured, sold, or distributed any copies of the plaintiff's drawings of the footwear. Even though the concept was the plaintiff's original creation, the court held that the copyright did not protect the copyright holder against the unauthorized manufacture of the socks. ${ }^{95}$

One can see, then, that copyright adds little, if anything, to trade secret protection. Nevertheless, a particular judge in a particular case might decide (incorrectly) that a copyright notice does provide an added defense against misappropriation of trade secrets. Therefore, from a practical standpoint, to mclude a copyright notice on docunrents containing trade secrets might be wise if no other probleins were created. Unfortunately, other problems are created.

\section{B. The Preemption Doctrine.}

Section 301(a) of the Act states that "all legal or equitable rights that are equivalent to any of the exclusive rights within the general scope of copyright . . . and come within the subject matter of copyright . . . are governed exclusively by this title."96 Section 301(b) modifies

93. See notes $27-42$ supra and accompanying text.

94. 428 F. Supp. 91 (E.D. Pa. 1977), aff'd, 568 F.2d 770 (3d Cir. 1978).

95. Id. at 92-94. See also Herbert Rosenthal Jewelry Corp. v. Honora Jewelry Co., 509 F.2d 64 (2d Cir. 1974); Herbert Rosenthal Jewelry Corp. v. Kalpakian, 446 F.2d 738 (9th Cir. 1971); PPS, Inc. v. Jewelry Sales Representatives, Inc., 392 F. Supp. 375 (S.D.N.Y. 1975). These cases hold that when a piece of jewelry has been copyrighted, the copyright does not confer a monopoly on the idea and does not prevent others from the manufacture and sale of such jewelry. These courts so held even though they acknowledge that the idea and its expression in a piece of jewelry are virtually indistinguishable. It should be noted that protection under the patent laws is available to truly novel discoveries that are marketed to the general public. The requirements for obtaining a patent are much stricter than those for acquiring a copyright because awarding a pateut amounts to giving one a monopoly on the underlying idea for a number of years. $C f$. Jack Adelman, Inc. v. Sonners \& Gordan, Inc., 112 F. Supp. 187, 188 (S.D.N.Y. 1934) (plaintiff's copyright of a drawing of a dress did not prevent the defendant from manufacturing the dress).

96. 17 U.S.C. $\$ 301$ (a) (1976). The subsection reads in its entirety:

On and after January 1,1978, all legal or equitable rights that are equivalent to any of the exclusive rights within the geueral scope of copyright as specified by section $106 \mathrm{~m}$ 
this statement, stating that "[n]othing in this title annuls or limits any rights or remedies under the common law or statutes of any State with respect to . . . activities violating legal or equitable rights that are not equivalent to any of the exclusive rights within the general scope of copyright as specified by section 106."97

These sections raise two problems that have not been answered definitively: what constitutes non-copyrightable subject matter that state law may regulate; and what constitutes a right equivalent to those rights granted under copyright law?98 $\mathrm{Phrased}$ in terms more appropriate to the issue at hand, these questions become: are trade secrets noncopyrightable subject matter regulated by state law; and are rights granted under trade secret law equivalent to those granted under the copyright law and therefore governed exclusively by federal law?

The answer to the first question, whether trade seccrets are noncopyrightable subject matter protected by state law, depends on the imterrelationship of sections 102, 103 and 301(a) of the Act. ${ }^{99}$ As noted earlier, section 102(a) provides copyright protection explicitly to: (1) literary works; (2) inusical works, including any accompanying words; (3) dramatic works, including any accompanymg music, (4) pantomimes and choreographic works; (5) pictorial, graphic, and sculptural works; (6) motion pictures and other audiovisual works; and (7) sound recordimgs. ${ }^{100}$ Section 103 adds compilations and derivative works to the list. ${ }^{101}$ Section 102(b) states explicitly that copyright protection does not extend to "any idea, procedure, process, system, method of operation, concept, principle, or discovery . . ."."102 Yet, none of these sections offers definitive guidelines to govern borderline cases. ${ }^{103}$ Where the secret in question clearly embodies an idea, pre-

works of authorship that are fixed in a tangible medium of expression and come within the subject matter of copyright as specified by sections 102 and 103 , whether created before or after that date and whether pubhished or unpublished, are governed exclusively by this title. Thereafter, no person is entitled to any such right or equivalent right im any such work under the common law or statutes of any State.

97. $I d . \$ 301(\mathrm{~b})(3)$.

98. See Katz, Copyright Preemption under the Copyright Act of 1976: The Case of Droit de Suite, 47 Geo. Wash. L. Rev. 200, 211 (1978).

99. Goldstem, supra note 87 , at 447 . See notes 50-53, 96-97 supra and accompanymg text.

100. 17 U.S.C. $\$ 102($ a) (1976).

101. Id. $\$ 103$.

102. $I d . \S 102(\mathrm{~b})$.

103. For instance, a list of names or a recipe are neither clearly copyrightable nor clearly uncopyrightable. A list of names may be viewed as a compilation, but it is unclear whether there is any expression involved that would afford the list copyright protection. A recipe, on the other hand, inay be original, but may im fact do no more than detail an idea and hence could be viewed as being ineligible for copyright protection. 
emption probably does not apply. ${ }^{104}$ But recipes, customer lists, and other materials that might look copyrightable can pose problems. ${ }^{105}$

One could read the Act as displaying an intent to include the elements of section 102(b) ${ }^{106}$ as part of copyright's subject matter even though these elements are left unprotected. Thus section 301 would remove these elements from state regulation. ${ }^{107}$ The use of the phrase "work of authorship" in section 102(b) ${ }^{108}$ might suggest that the items listed there are origmal works of authorship and thus are within the subject matter of copyright. ${ }^{109}$ Therefore, state law affording protection to these items would be subject to preemption although copyright law does not protect these items. ${ }^{110}$ In other words, the items contamed in section 102(b) would not be protected at all.

The better interpretation allows the states to protect the items histed in section 102(b). Under this interpretation of section 102(b) certain elements-such as ideas, procedures, and processes-are not within the scope of federal copyright law even though they are contamed in works of authorship. ${ }^{111}$ This interpretation is im accord with existing case law. ${ }^{112}$

It is also unclear what constitutes the "equivalent" rights of section 301(b)(3). ${ }^{113}$ Prior to the adoption of the Act, subsection 301(b)(3) histed specific rights that were not to be preempted by federal law, including rights agaimst misappropriation, breaches of contract, breaches of trust, trespass, conversion, invasion of privacy, defamation, and deceptive trade practices. ${ }^{114}$ Congressman Sieberling proposed a lastminute amendment which struck these examples froin the bill and substituted the present language. ${ }^{15}$ The reasons for this amendment are unclear. Congressman Sieberling stated that his intention was to prevent the nullification of section 301 by the "inclusion of certain examples in the exemptions from preemption." 16 He noted that the Justice Department strongly supported his amendment, especially with regard to the doctrine of misappropriation. ${ }^{117}$ A subsequent conversation be-

104. Goldstein, supra note 87 , at $447-48$.

105. Id. 448. See note 103 supra.

106. 17 U.S.C. $\$ 102(b)$ (1976).

107. Goldstein, supra note 87 , at 448 .

108. 17 U.S.C. $\$ 102(b)$ (1976). See note 53 supra.

109. "Copyright protection subsists . . . in original works of authorship . . .." 17 U.S.C.

§ 102(a) (1976); see Goldstein, supra note 87, at 448.

110. Goldstein, supra note 87 , at 448 .

111. Id.

112. See notes 53-58 supra and accoinpanying text.

113. 17 U.S.C. \& 301(b)(3) (1976). See text accompanying note 97 supra.

114. S. 22, 94th Cong,, 2d Sess., 122 CoNG. REc. 31997 (1976).

115. 122 CoNG. REC. 32015 (1976).

116. Id.

117. Id. 
tween Congressmen Sieberling and Railsback obfuscated the amendment's purpose, however, and left open the question of the status of the stricken examples. ${ }^{118}$

Similarly, the case law regarding federal copyright preemption does not provide a uniform basis for deciding what constitutes "equivalent" rights. In 1964 the Supreme Court, in Sears, Roebuck \& Co. v. Stiffel Co. ${ }^{119}$ and Compco Corp. v. Day-Brite Lighting, Inc., ${ }^{120}$ appeared to give federal patent and copyright law a wide preemptive sweep. The Court held that state laws that give protection equivalent to federal patent or copyright law impermissibly interfere with the federal scheme for protecting creativity, even if federal law does not provide protection in the particular case.121 The Court modified this doctrime in Goldstein v. California, 122 upholding a state statute that provided criminal penalties for record piracy even though the statute extended a type of protection equivalent to copyright law. The Court took the view that, absent a clear federal statutory command, states are free to protect subject inatter that federal law does not specifically address. ${ }^{123}$ The Court's decision in Kewanee Oil Co. v. Bicron Corp. ${ }^{124}$ further modified the Sears-Compco doctrine. Kewanee upheld Ohio's trade secret law agaimst a claim of federal preemption. ${ }^{125}$ The Kewanee Court analyzed the economic objectives and effects of trade secret and patent law and concluded that state systems would siphon few inven-

\footnotetext{
118. The conversation proceeded as follows:

Mr. RaIlsBaCK. Mr. Chairman, may I ask the gentleman from Ohio for the purpose of clarifying the amendment, that by striking the word "misappropriation," the gentleman in no way is attempting to change the existing state of the law, that is as it may exist in certain States that have recognized the right of recovery relating to misappropriation; is that correct?

Mr. SieberLiNG. That is correct. All I am trying to do is prevent the citing of thein as examples in a statute. We are, in effect, adopting a rather amorphous body of State law and codifying it, in effect. Rather I am trying to have this bill leave the State law alone and make it clear we are merely dealing with copyright laws, laws apphicable to copyrights.

MR. RAILSBACK. Mr. Chairman, I personally have no objection to the gentleman's amendment in view of that clarification and I know of no objections from this side.
} Id.

119. 376 U.S. 225 (1964) (holding that a state unfair competition law may not prohibit the copying of a pole lamp that was not patentable and not copyrightable).

120. 376 U.S. 234 (1964) (holding that a state unfair competition law may not prohibit nor award damages for the copying of the design of a lighting fixture that was the subject of an invalid design patent).

121. See Sears, Roebuck \& Co. v. Stiffel Co., 376 U.S. 225, 231-32 (1964); Coinpco Corp. v. Day-Brite Lighting, Inc., 376 U.S. 234, 237-39 (1964).

122. 412 U.S. 546 (1973).

123. Id. at $558-59$.

124. 416 U.S. 470 (1974).

125. The Court noted that article I, section 8 , clause 8 of the Constitution does not vest exclusive power over discoveries in Congress nor does it bar state regulatory power. $I d$. at 478-79. 
tions away from the federal protective scheme. ${ }^{126}$ The Court made no effort, however, to overrule the Sears-Compco doctrine. ${ }^{127}$

As a result of these cases, the precise dimensions of federal preemption of state law are "matter[s] of difficulty and confusion." 128 Courts are willing to follow the broad doctrine of Sears and Compco to allow preemption when the subject matter is of a type covered by the copyright laws, ${ }^{129}$ even if preemption should not occur.

A recent federal district court case, Avco Corp. v. Precision Air Parts, Inc. ${ }^{130}$ supports this observation. In $A v c o$ the plaintiff brought state causes of action for misappropriation of trade secrets, unfair competition, and common law copyright infringement. ${ }^{131}$ These causes of action allegedly arose when the defendant "improperly utilized" the plaintiff's secret designs of airplane parts in designing similar parts. ${ }^{132}$ Although the case probably could have been decided under the Alabama statute of himitations, the court held that section 301 preempted each of the state causes of action. ${ }^{133}$ The $A v c o$ court outlined three requirements that must be met before a state cause of action is preempted by federal law. First, the cause of action must "relate" to rights that are equivalent to the exclusive rights belonging to a copyright holder. Second, the work at issue must be fixed in a tangible mediuin of expression. Third, the facts must concern a work that is within the subject matter of copyright. ${ }^{134}$ The court then noted erroneously that

126. Id. at 484-92. The Kewanee Court adopted the approach used in Painton \& Co. v. Bourns, Inc., 442 F.2d 216 (2d Cir. 1971), and distinguished between three categories of trade secrets: (1) secrets believed by the owner to be validly patentable; (2) secrets known by the owner not to be patentable; and (3) secrets believed by the owner to be of dubious patentability. 416 U.S. at 484 . The Court felt that an inventor of a validly patentable invention is likely to opt for the stronger patent protection. Id. at 489-91. Nonpatentable inventions could not be patented anyway. Id. at 484-85. The Court also noted that an inventor of a dubiously patentable invention would probably atteinpt to acquire the "superior" rewards of patent protection. Id. at 487-89.

127. See 416 U.S. at $479-93$. 1979).

128. Synercoin Technology, lnc. v. University Coinputing Co., 474 F. Supp. 37, 40 (N.D. Tex.

129. Id. In Synercom the developer of input formats, instruction manuals, and related services for a structural analysis computer program alleged that his competitors had engaged in unfair competition by designing a structural analysis package designed spccifically to be adaptable to the developer's input inethodology and by aiming their niarketing prograin at the developer's accounts. The court held that because it had already granted rclief for copyright infringement, further relief under the theory of unfair competition was unwarranted.

130. 2 Copyright L. REP. (CCH) If 25,207 (M.D. Ala. 1980).

131. Id. at 16,156 . Common law copyright no longer exists in works created after January 1 , 1978 , because federal copyright law governs a work from the moinent of its creation. See text accompanying note 70 supra.

132. 2 COPYRIGHT L. REP. at 16,156 .

133. Id. at 16,160 .

134. Id. at 16,157 . 
"[t]he essence of Plaintiff's complaimt is that Defendant has copied its drawings and specifications and prepared derivative works based upon those drawings and specifications. Thus, the complaint fits squarely into $\S 106(1)$ and (2)."135 Actually, the plamtiff was (or should have been) complaining that the defendant had misappropriated the plaintiff's ideas. After finding that the drawings and specifications were fixed in a tangible medium of expression and that they could be characterized as pictorial or graphic works, the court held that the plaintiff's cause of action for misappropriation of trade secrets showed no grounds to "allow the coininon law rights of 'trade secrets' to avoid preemption."136 The court so held, even though trade secret law and copyright law protect different things, and there was no evidence of any explicit copying. This decision, in effect, afforded the plaintiff no protection for the valuable ideas contained in its drawings but only for the specific expression of those ideas.

By placing a copyright notice upon trade secrets then, the proprietor of the secret takes the risk that state trade secret law will be mistakenly preempted by federal copyright law. As discussed earlier, however, copyright law is not designcd to protect ideas, only their expression. ${ }^{137}$ Hence, if the proprietor of the secret idea loses it to one who uses the idea, the copyright laws will not afford the proprietor the kind of protection he desires. Ultimately, the proprietor can be left without a reinedy under both bodies of law.

\section{The Deposit Requirement.}

One final problem remains with placing a copyright notice on trade secrets. To maintain an infringement action, one inust meet the requirements for registration of a copyright. ${ }^{138}$ To complete registration, one inust deposit at least "one complete copy or phonorecord" at the Copyright Office. ${ }^{139}$ Deposited articles are open to public imspec-

135. Id.

136. Id. at 16,159. The American Bar Association Section of Patent, Trademark and Copyright Law recently adopted Resolution 206-1, which indicates that the Section "favors im principle the non-preeinption of state trade secret law by the copyright law" and also that "the Section favors the amendment of Section 301 of the 1976 Copyright Act to clarify that preemption under such statute does not extend to trade secret law." A.B.A. Section of Patent, Trademark AND Copyright Law, Summary of Proceedings 30 (1981). The Section took this action because, as one member noted, "The Copyright Act does not preempt trade secret protection. But judges can fall into error or be pushed into it by defense counsel, and it is therefore desirable that the statute be clarified ...."Id. 61. For a decision in line with the Section's approach, see Warrington Assocs. v. Real-Time Eng'r Syss., Inc., 522 F. Supp. 367 (N.D. I11. 1981).

137. See notes 53-58 supra and accompanying text.

138. See 17 U.S.C. $\$ 411$ (1976).

139. Id. $\S 408(\mathrm{~b})$. 
tion and are available for viewing during the term of the copyright. ${ }^{140}$ Thus, to bring a copyright infringement action, the holder of a trade secret has to disclose the secret. Once the element of secrecy is lost, it is difficult to pursue an action under trade secret law. ${ }^{141}$

It has been suggested that the Copyright Office should keep the deposited copy confidential for those who request that their works be kept private. ${ }^{142}$ Section 407 (c) of the Act provides an exemption to the deposit requirement if the requirement would cause "practical hardships," 143 and it has been proposed that this section be expanded to include trade secrets. ${ }^{144}$ Nonetheless, this expansion would work against the constitutional purpose of copyright law-advancing science and the useful arts ${ }^{145}$-because it would give the copyright holder a nnonopoly on his expression of the idea for his lifetime plus fifty years ${ }^{146}$ without exacting the quid pro quo of disclosure. Disclosure allows others to examine the copyrighted expression and its underlying ideas and to learn froin the work of the copyright proprietor. ${ }^{147}$ Freedo1n not to disclose would discourage this learning process.

\section{CONCLUSION}

Using copyright law to protect trade secrets is madvisable. Copyright law protects expressions, not ideas, and ideas are the valuable coinponent of trade secrets. Hence, copyright affords no additional protection for trade secrets. Indeed, there are two reasons why copyrighted trade secrets might ultimately be afforded less protection than secrets not copyrighted. First, placing a copyright notice on a trade secret affords a court the opportunity to decide that section 301 of the Act preenpts applicable state trade secret law. When only copyright law applies, ideas are no longer protected. Second, to enforce rights under copyright, copies of the trade secret must be deposited at the

140. Id. $\S \S 408(\mathrm{~b})(1), 704(\mathrm{~d}), 705(\mathrm{~b})$.

141. See notes 23-26 supra and accompanying text.

142. Comment, Copyright and Privacy Protection of Unpublished Works-The Author's Dilemma, 13 Colum. J.L. \& Soc. Prob. 351, 381 (1977). See also A.B.A. Section of Patent, Trademark and Copyright Law, Committee Reports 218 (1980).

143. 17 U.S.C. $\S 407$ (c) (1976).

144. A.B.A. Section of Patent, Trademark and Copyright Law, Committee Reports 218 (1980). Section 408(c)(1) of the Act authorizes "the deposit of identifying material instead of copies or phonorecords . . ." 17 U.S.C. $\S 408(c)(1)$ (1976). This "substitute deposit" idea has also been offered as a way to prevent the disclosure of copyrighted trade secrets. See Comment, supra note 142, at 381-82. However, Congress intended this section to provide for the filing of objects that were bulky, unwieldy, easily broken, or otherwise impracticable to file. Id.

145. See notes 87-89 supra and accompanying text.

146. See text accompanying note 72 supra.

147. See notes 79-89 supra and accompanying text. 
Copyright Office. This requirement amounts to public disclosure of the secret, eliminates trade secret protection, and once agam strips protection away from confidential ideas. Therefore, it is best not to copyright documents containing trade secrets. The concept of copyright is not flexible enough to add to the already adequate protection of trade secret laws and may actually cause this protection to be forfeited.

Stephen M. Dorvee 